\title{
Olanzapine-induced Convulsive Status Epilepticus: A case report from Eastern Nepal
}

\author{
Shah $\mathbf{B}^{1}$, Taparia $\mathbf{R}^{2}$, Mishra $\mathrm{A}^{3}$ \\ 1. Assistsnt Professor, Dept. Of Internal Medicine, BPKIHS, Dharan 2.Lecturer, Dept. Of Internal \\ Medicine, BPKIHS, Dharan 3. Junior Resident, Dept. Of Internal Medicine, BPKIHS, Dharan \\ E-mail *Corresponding author: doctorbhupen@gmail.com
}

\begin{abstract}
The premarketing surveillance showed that the incidence of olanzapine-induced seizure was $0.88 \%$. However, the data of post-marketing surveillance of olanzapine-induced seizure was limited. The causal effect of olanzapineinduced seizure was not established yet. We report a case of a 48-year old female who had olanzapine-induced convulsive status epilepticus. Olanzapine was used for the treatment of post-capsular ischemic stroke hemichorea. Olanzapine can induce generalized tonic-clonic, focal and myoclonic seizure. An olanzapine-induced seizure is often self-limited with drug withdrawal. However, few patients with olanzapine-induced therapy need anticonvulsant therapy. Olanzapine can induce the seizure especially in patients with multiple medical co-morbidities.
\end{abstract}

Keywords: Olanzapine, Seizure, Status Epilepticus

\section{INTRODUCTION}

Olanzapine is an atypical antipsychotic that has affinity for dopamine, serotonin, histamine, adrenergic and muscarinic receptors. ${ }^{1}$ The atypical antipsychotics have a higher risk for electroencephalographic changes than typical antipsychotics. 2 Among the atypical antipsychotics, not only clozapine but also olanzapine and quetiapine carries a higher risk for seizure than expected. This literature was confounded by the presence of medical comorbidities, preexisting seizure disorder, and drug withdrawal. 3 The premarketing surveillance showed the incidence of olanzapine-induced seizure was $0.88 \%$. 4 However, the data regarding the post-marketing surveillance of olanzapine-induced seizure is limited. The causal effect of olanzapine-induced seizure was not established yet. We report a case of a 48-year-old female who had olanzapineinduced convulsive status epilepticus.

\section{CASE- REPORT}

A 48-year-old female presented to the medical outpatient department of Internal Medicine of B.P. Koirala Institute of Health Sciences with a history of sudden onset of abnormal irregular jerky movement of the left hand for 12 hours. It was aggravated by lifting the hand and relieved by resting state and sleep. It was restricted to the left hand. She also had a complaint of a decrease in left grip strength. There was no history of a headache, fever, trauma and illicit drug intake. Past history- She was a case of type 2 diabetes mellitus and was taking Metformin $2 \mathrm{gm}$ and Glimepiride $4 \mathrm{mg}$ per day. There was no history of any psychiatric co-morbidities and seizure disorder. She was a non-smoker and non-alcoholic. On examination finding Glasgow coma scale score - 15/15, BP- 100/60 mmHg, Pulse rate- 72 beat /minute regular rhythm, Respiratory rate- 16 cycle /minute, temperature$98^{\circ} \mathrm{F}$. On Central nervous system examination revealed left wrist flexion power- $4 / 5$ and left wrist extension power $4 / 5$. She had semipurposive, non- repetitive, non-rhythmic and irregular movement in left hand. Other central examination, respiratory system, cardiovascular and gastrointestinal system revealed no abnormality. The provisional diagnosis of hemichorea was made. 


\section{INVESTIGATIONS}

The baseline investigation findings of the patient are illustrated in Table 1. As shown in figure 1. the Computed tomography of the patient showed the lacunar infarct of the right internal capsule. The diagnosis of Post- internal capsule stroke chorea was made. Electroencephalogram was done on $2^{\text {nd }}$ of seizure activity which showed the generalized epileptiform discharges is shown in Figure 2.

Table 1: Baseline investigation reports of the Patient

\begin{tabular}{|l|l|l|}
\hline Paramaters & Value & Normal value \\
\hline Haemoglobin & $13 \mathrm{~g} / \mathrm{dl}$ & $11-16 \mathrm{~g} / \mathrm{dl}$ \\
\hline $\begin{array}{l}\text { Total leucocyte } \\
\text { count }\end{array}$ & $\begin{array}{l}10500 \\
\text { cell/mmcu }\end{array}$ & $\begin{array}{l}40000-11000 \\
\text { cell } / \mathrm{mmcu}\end{array}$ \\
\hline Platelet & $\begin{array}{l}400000 \\
\text { cell/mmcu }\end{array}$ & $\begin{array}{l}150000- \\
400000 / \mathrm{mmcu}\end{array}$ \\
\hline $\begin{array}{l}\text { Random blood } \\
\text { sugar }\end{array}$ & $350 \mathrm{mg} / \mathrm{dl}$ & $<140 \mathrm{mg} / \mathrm{dl}$ \\
\hline Urea & $32 \mathrm{mg} / \mathrm{dl}$ & $10-50 \mathrm{mg} / \mathrm{dl}$ \\
\hline Creatinine & $0.7 \mathrm{mg} / \mathrm{dl}$ & $0.5-1.5 \mathrm{mg} / \mathrm{dl}$ \\
\hline Sodium & $141 \mathrm{mmol} / \mathrm{L}$ & $136-145 \mathrm{mmol} / \mathrm{L}$ \\
\hline Potassium & $3.8 \mathrm{mmol} / \mathrm{L}$ & $3.5-5 \mathrm{mmol} / \mathrm{L}$ \\
\hline Calcium total & $9.5 \mathrm{mg} / \mathrm{dl}$ & $8.4-10.2 \mathrm{mg} / \mathrm{dl}$ \\
\hline Ionized calcium & $0.94 \mathrm{mg} / \mathrm{dl}$ & $1.05-1.27 \mathrm{mg} / \mathrm{dl}$ \\
\hline Urine ketones & Negative & \\
\hline Hb & $5.2 \%$ & $5.5-6.4 \%$ \\
\hline $\begin{array}{l}\text { Serum } \\
\text { bicarbonate }\end{array}$ & $22 \mathrm{mmol} / \mathrm{L}$ & $20-24 \mathrm{mmol} / \mathrm{L}$ \\
\hline $\begin{array}{l}\text { Abbreviation: } \mathrm{Hb} \text { A1C- Glycated haemoglobin, g/dl-gram/deciliter, } \\
\text { mg/dl-milligram/deciliter }\end{array}$ \\
\hline
\end{tabular}

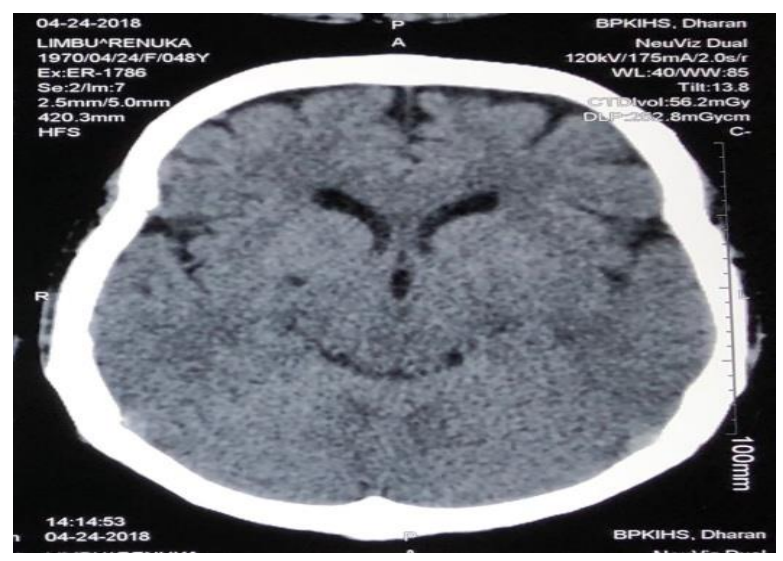

Figure 1: Computed tomography of Head showing right internal capsular ischemic stroke

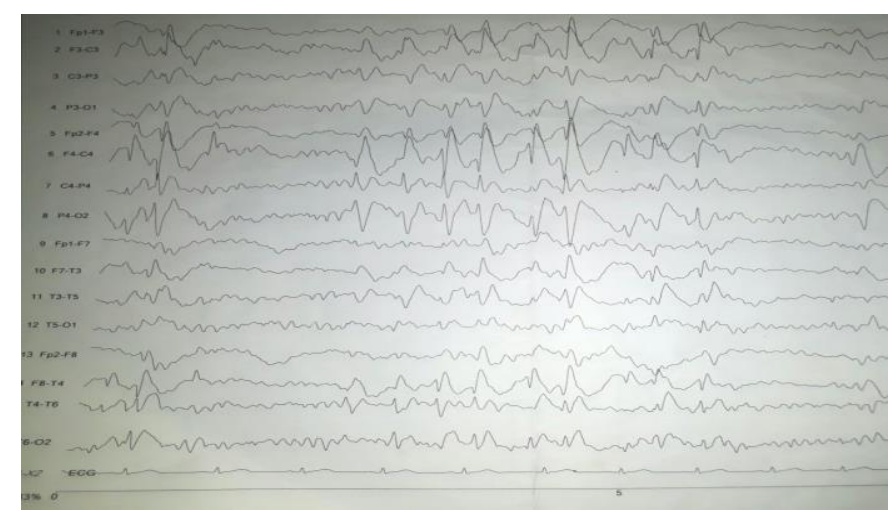

Figure 2: Electroencephalography of a patient showing generalized epileptiform discharges

\section{TREATMENT:}

We prescribed aspirin 300mg followed by $75 \mathrm{mg}$ once daily, atorvastatin $20 \mathrm{mg}$ once daily, Injection Glargine 14 IU Subcutaneous once daily. One second day of admission Olanzapine $2.5 \mathrm{mg}$ tablet was prescribed once daily for hemichorea. After four hours of intake of Olanzapine, she had Generalised tonic-clonic seizure repeatedly for one hour without regaining consciousness. The seizure was treated initially with and lorazepam $5 \mathrm{mg}$ three doses but was not controlled. Injection Levetiracetam $2000 \mathrm{mg}$ in $100 \mathrm{ml}$ normal saline was given over one hour. After initiating levetiracetam, the seizure was controlled and she regained consciousness after six hours. Repeated Computed Tomography of the head showed no new changes. She was discharged on Tablet levetiracetam $500 \mathrm{mg}$ twice a day, injection glaring 14 IU once a day, injective glulisine 10 IU SC thrice a day, Tablet aspirin 75 $\mathrm{mg}$ once daily, and tablet atorvastatin $20 \mathrm{mg}$ once daily.

\section{FOLLOW UP}

She followed our outpatient department after two weeks. There was no new seizure activity. Tablet levetiracetam was tapered to $250 \mathrm{mg}$ twice daily.

\section{DISCUSSION:}

We reported a case of Olanzapine-induced convulsive status epilepticus in a 48-year-old patient with Post-capsular stroke hemichorea. She recovered from status epilepticus with the 
stoppage of olanzapine and use of Levetiracetam.

Chorea is an unusual complication and observed in less than $1 \%$ of cases of acute stroke. Post-stroke chorea is treated with the typical or atypical antipsychotic agents. Our patient had post-stroke chorea due to the involvement of right internal capsule ischemic infarct..She was treated with Olanzapine $5 \mathrm{mg}$ as the advantage of using atypical antipsychotics in the management of post-stroke chorea are a lower rate of parkinsonism, delayed dyskinesia and recurrent stroke. ${ }^{5-7}$ Olanzapine was used to treat the chorea as reported by Dipple HC. ${ }^{8}$

Olanzapine intake induced the convulsive seizure in our patient. Similar to our case report, Behere RV et al reported the case of the 25-yearold man who had a generalized tonic-clonic seizure after exposure to tab olanzapine 20 md/day. ${ }^{9}$ Anzelloti F et al reported the focal motor seizure in a 47-year-old male of paranoid schizophrenia after intake of olanzapine tablet. 10 Similarly, Camocha et al reported the olanzapine-induced myoclonic seizure with olanzapine $2.5 \mathrm{mg}$ twice daily dose. 11 Olanzapine can induce a different type of seizure.

Most of the seizure induced by olanzapine was controlled after withholding the olanzapine, however, Wyderski $\mathrm{R} \mathrm{J}$ et al. reported the fatal status epilepticus in a 41-year old patient taking olanzapine for bipolar disorder. Our patient recovered from the convulsive status epilepticus probably because of early control of seizure with the use of anticonvulsant in a hospital setting. We have discharged our patient on tab levetiracetam and plan to continue the levetiracetam till normalization of EEG activity as recommended by the $U$ Iqraa et al. 12 Although symptomatic seizure, an olanzapineinduced seizure may require anticonvulsant in view of status epilepticus.

Strength: This is the first case of olanzapineinduced convulsive status epilepticus reported from Nepal.

Limitation: We Couldn't perform serum level of olanzapine in blood.

\section{CONCLUSION:}

Olanzapine can induced seizure activity. We must be watchful to the epileptogenic potential of the olanzapine especially in the individual who has multiple co-morbidities. Psychotic disorder and seizure disorder can occur concurrently, Physicians must be cautious regarding the use of olanzapine for management of psychotic symptoms in a seizure disorder.

ACKNOWLEDGEMENT: We would like to acknowledge patient and patient's attendant for giving us written informed consent for this case report.

\section{CONFLICT OF INTEREST: None}

\section{REFERENCES:}

1. Fulton B G. Olanzapine: a review of its pharmacological properties and therapeutic efficacy in the management of schizophrenia and related psychoses. Drugs 1997; 53: 281-98.

2. Centorrino F, Price BH, Tuttle M, Bahk WM, Hennen $J$, Albert MJ BR. EEG abnormalities during treatment with typical and atypical antipsychotics. Am J Psychiatry 2002; 159: 109-15.

3. Lertxundi $U$, Hernandez $R$, Medrano J, et al. Antipsychotics and seizures: Higher risk with atypicals? Seizure 2013; 22: 141-143.

4. Alper K, Schwartz KA, Kolts RL KA (2007). Seizure incidence in psychopharmacological clinical trials: an analysis of Food and Drug Administration (FDA) summary basis of approval reports. Biol Psychiatry 2007; 62: 345-54.

5. Liperoti, R.; Gambassi, G.; Lapane, K.L.; Chiang, C.; Pedone, C.; Mor V. BR. Cerebrovascular events among elderly nursing home patients treated with conventional or atypical antipsychotics. J Clin Psychiatry 2005; 66: 1090-1096.

6. Bashir K. Clozapine for the control of hemiballismus. Clin Neuropharmacol,; 17: 477-480.

7. Handley A, Medcalf P, Hellier K, Dutta D. Movement disorders after stroke. Age Ageing, 2009, 38, 260-266. Age Ageing, 2009; 38: 260-266.

8. Dipple HC. The use of olanzapine for movement disorder in Huntington disease: a first case report. J Neurol Neurosurg Psychiatry 1999; 67: 123-124.

9. Behere RV, Anjith D, Rao NP, et al. Olanzapineinduced clinical seizure: a case report. Clin Neuropharmacol 2009; 32: 297-298.

10. Anzellotti F, Capasso M, Frazzini V, et al. Olanzapinerelated repetitive focal seizures with lingual dystonia. Epileptic Disord 2016; 18: 83-86.

11. Camacho A, Garcia-Navarro M, Martinez B, Villarejo A PE. Olanzapine-induced myoclonic status. Clin Neuropharmacol 2005; 28 145-7 2005; 28: 145-7.

12. Iqraa $U$, Hospital I, Health M. Olanzapine Induced Seizures : A Case Report OLANZAPINE INDUCED SEIZURES : A CASE REPORT. 2015; 2: 1-2. 